\title{
sciendo
}

CIVIL AND ENVIRONMENTAL ENGINEERING REPORTS

E-ISSN 2450-8594

CEER 2018; 28 (3): 005-016

DOI: $10.2478 /$ ceer-2018-0031

Original Research Article

\section{THE EFFICIENCY OF NITROGEN COMPOUNDS REMOVAL IN WASTEWATER TREATMENT PLANT}

\author{
Monika SUCHOWSKA-KISIELEWICZ ${ }^{1}$, Aleksandra SIECIECHOWICZ, \\ Zofia SADECKA \\ University of Zielona Gora, Zielona Góra, Poland
}

\begin{abstract}
In sewage treatment plants for removing nitrogen compounds are used biological processes of nitrification and denitrification. The parameters determining the efficiency of biological processes of nitrogen removal are organic carbon ratio $\left(\mathrm{BOD}_{5}\right)$ to total Kjeldahl nitrogen $(\mathrm{TKN})$, temperature and $\mathrm{pH}$. The impact of these parameters on the operation of the sewage treatment plant with an RLM of 45,000 based on operational data from the period 2011-2013 has been assessed. The efficiency of removing nitrogen compounds from sewage in the analysed treatment plant depended on the temperature of sewage and the quotient $\mathrm{BOD}_{5} / \mathrm{TKN}$. Even at the optimal ranges of $\mathrm{BOD}_{5} / \mathrm{TKN}$ ratio temperature at $10^{\circ} \mathrm{C}$ nitrogen concentration in the treated wastewater was about 3 times higher than the limit value, and the removal efficiency of nitrogen varied between about 30 to $60 \%$.
\end{abstract}

Keywords: nitrogen removal, $\mathrm{BOD}_{5} / \mathrm{TKN}$ ratio, wastewater temperature

\section{INTRODUCTION}

Achieving stable conditions for effective biological removal of nitrogen and phosphorus from municipal wastewater is an important and difficult task of operating. While the efficiency of removal of phosphorus from wastewater

${ }^{1}$ Corresponding author: University of Zielona Góra, Institute of Environmental Engineering, Szafrana 15, 65-246 Zielona Góra, Poland, e-mail: m.suchowska-kisielewicz@iis.uz.zgora.pl, tel. +48683282560 
successfully may be assisted chemical precipitation, in the case of removal of nitrogen compounds to obtain normalized concentrations in treating wastewater requires continuous control and an intensification of biological processes. In wastewater treatment, nitrification occurs in technical systems, low load and denitrification systems at high load. These processes, therefore, require different environmental conditions: aerobic for nitrification and anaerobic - for denitrification introduced into the technological system of treatment - for denitrification or anaerobic-aerobic conditions for biological phosphorus removal $[2,7]$.

In a mixed population of nitrification bacteria and heterotrophic growth rate of nitrifying bacteria besides concentration of ammonia nitrogen and dissolved oxygen also influenced other factors.

The most important include the ratio of organic carbon $\left(\mathrm{BOD}_{5}\right)$ to Total Kjeldahl Nitrogen (TKN) and the temperature and $\mathrm{pH}$ of the environment. The dependence between the number of nitrifying bacteria in the biomass sludge, and the ratio of $\mathrm{BOD}_{5} / \mathrm{TKN}$ is shown in Table 1 [7].

Table 1. The relationship between the share of nitrification bacteria in the biomass sludge, and the ratio of $\mathrm{BOD}_{5} / \mathrm{TKN}$

\begin{tabular}{|c|c|c|c|}
\hline $\mathrm{BOD}_{5} / \mathrm{TKN}$ & $\begin{array}{c}\text { The share of } \\
\text { nitrifying bacteria }\end{array}$ & $\mathrm{BOD}_{5} / \mathrm{TKN}$ & $\begin{array}{c}\text { The share of } \\
\text { nitrifying bacteria }\end{array}$ \\
\hline 0.5 & 0.35 & 5 & 0.054 \\
1 & 0.21 & 6 & 0.043 \\
2 & 0.12 & 7 & 0.037 \\
3 & 0.083 & 8 & 0.033 \\
4 & 0.064 & 9 & 0.029 \\
\hline
\end{tabular}

The value of the ratio of $\mathrm{BOD}_{5} / \mathrm{TKN}$ is larger the share of nitrifying bacteria in a mixed population of activated sludge are smaller. The ratio of $\mathrm{BOD}_{5} / \mathrm{TKN}$ located in the range of 0.5 to 3 is a typical value for nitrification by the nitrifying bacteria share of the total biomass in the range of 0.35-0.083 (Table 1). When the wastewater treatment system occurs oxidation of organic carbon and ammonium nitrogen then the ratio of $\mathrm{BOD}_{5} / \mathrm{TKN}$ is usually greater than 5 and the proportion of nitryfikatorów is less than $5.4 \%$.

Temperature has a significant effect on the rate of nitrification [2, 3, 8]. Along with its decline, the rate of nitrification also decreases. From temperature change depends on both the value of the maximum growth rate of nitrification bacteria $\mathrm{K}_{\mathrm{N}} \max$ and the value of the constant Michaelis-Menten for ammonia nitrogen $\mathrm{K}_{\mathrm{N}}$.

Significant effect on the nitrification has also a $\mathrm{pH}$ value optimal for which nitrification process is in the range 7.2-9.0. 
The efficiency of nitrogen removal from wastewater is often limited by the unsatisfactory efficiency of the denitrification process, which in turn is associated with a low content of readily assimilable organic substrates in the influent wastewater. The process of denitrification takes place without disruptions when the ratio of $\mathrm{BOD}_{5} / \mathrm{N}^{-N} \mathrm{O}_{3}$ is greater than 3.5 and $\mathrm{BOD}_{5} / \mathrm{TKN}$ in the range of $3.5-5[2,7,8]$. At lower values of this ratio, it is necessary to add to the wastewater, organic compounds, and then denitrification are carried out with an external carbon source. As an external carbon source can be used as methanol, ethanol, acetic acid, organic acids, sewage, brewer sugar wastewater, etc.; In which the ratio of $\mathrm{BOD}_{5}$ of total nitrogen is relatively large. Easily to obtain the carbon source in the wastewater treatment are volatile fatty acids (VFA), which can be produced in acid fermentation of initial or excessive sludge. The unfavourable share of organic carbon to nitrogen is currently frequently appearing problem in wastewater treatment plants.

If denitrification is not going well, despite the appropriate values of the ratio $\mathrm{C} / \mathrm{N}$, the limiting factor in this process may be a degree of internal recirculation (recycling the $\mathrm{N}^{-\mathrm{NO}_{3}}$ ) and wastewater temperature. The optimum temperature for denitrification is $20^{\circ} \mathrm{C}$, and with its reduction, the efficiency of denitrification decreases. At temperatures below $5^{\circ} \mathrm{C}$, the rate of denitrification is approx. $20 \%$ of the rate achieved at $20^{\circ} \mathrm{C}$. Apart from temperature, factor influencing the degree of denitrification, is $\mathrm{pH}$, which optimal value should be within the range 6.5-7.5.

The process is rapidly inhibited if the $\mathrm{pH}$ falls to a value below $\mathrm{pH} 6.0$ or $\mathrm{pH}$ value exceeds 8.0.

The presence of oxygen inhibits the denitrification process. If the wastewater is dissolved oxygen, it becomes an electron acceptor instead of nitrates, as the rate of nitrate reduction by microorganisms is less than the rate of aerobic respiration of the cells. Therefore, the oxygen concentration in the biological reactor should not exceed $0.5 \mathrm{gO}_{2} / \mathrm{m}^{3}$. Factors that influence favourably the process of denitrification is $[1,8,9,10]$ :

- The ratio of nitrogen to $\mathrm{BOD}_{5}$ in the supply of less than 0.2 ,

- No pre-settler (if permitted by the treatment system) or the short duration of the pre-sedimentation (e.g. 20 minutes in dry weather),

- High ratio of $\mathrm{BOD}_{5}$ after filtration to total $\mathrm{BOD}_{5}$,

- Pre-acidification wastewater,

- Alignment of the concentrations and amounts of supply. Factors influencing negatively on the process of denitrification (because, for example, they reduce the necessary $\mathrm{BOD}_{5}$ value) are $[1,8]$ :

- A large share of random water supply and sewage general-navigable, 
- Reduction of the concentration of rapidly decaying fraction $\mathrm{BOD}_{5}$ in the sewage system,

- Long retention time in the initial settlers, without pre-acidification

- Pre-precipitation,

- The ratio of nitrogen to $\mathrm{BOD}_{5}$ at the inlet greater than 0.3,

- Low quotient $\mathrm{BOD}_{5}$ after filtration to $\mathrm{BOD}_{5}$ total,

- Bringing oxygen into the denitrification

- Different timelines of the content of organic compounds $\left(\mathrm{BOD}_{5}\right)$ and nitrogen in inflow.

The paper presents the assessment of the mechanical and biological efficiency of sewage treatment plants with the capacity of $\mathrm{Q}=6,000 \mathrm{~m}^{3} / \mathrm{d}$ and the equivalent number of inhabitants of $\mathrm{PE}=45,000$ based on operational data from the period 2011-2013 The analysis included both the removal of organic compounds and nutrients from wastewater, with particular emphasis on the impact of temperature and the ratio of $\mathrm{BOD}_{5} / \mathrm{TKN}$.

\section{CHARACTERISTICS OF WASTEWATER TREATMENT PLANT}

The analysed sewage treatment plant was built in the $70 \mathrm{~s}$ as a mechanical treatment, whose main feature was the settler Imhoff. In 2001-2003, the treatment plant was thoroughly modernized and now she works in technology, mechanicalbiological treatment of waste water with the chemical precipitation of phosphorus. Continued treatment technology consists of the following features:

- Grille dense stepped,

- Expansion chamber,

- Grit has blown PISTA,

- Primary settling tank - settler Imhoff,

- Chamber phosphorus removal,

- Aeration activated sludge with simultaneous nitrification and denitrification and chemical precipitation of phosphorus,

- Secondary sedimentation tank, radial,

- Installation of dewatering sludge press sieve-belt.

The wastewater flowing into wastewater treatment come from households, public facilities, industrial waste from the food industry, wood and metal and from the vacuum trucks [5]. The wastewater treatment plant has been designed to yield: $\mathrm{Q}=6,000 \mathrm{~m}^{3} / \mathrm{d}$ and $\mathrm{Q}_{\max }=720 \mathrm{~m}^{3} / \mathrm{d}$.

According to the Regulation of the Minister of the Environment of November 18, 2014 treated wastewater should be to the following levels [6]: 
- $\mathrm{BOD}_{5}$

- $\mathrm{COD}$

- TKN

- Phosphorus

- TSS

\author{
$15.0 \mathrm{mg} \mathrm{O} / \mathrm{dm}^{3}$ \\ $125.0 \mathrm{mg} \mathrm{O} / \mathrm{dm}^{3}$ \\ $15.0 \mathrm{mg} \mathrm{N} / \mathrm{dm}^{3}$ \\ $2.0 \mathrm{mg} \mathrm{P} / \mathrm{dm}^{3}$ \\ $35.0 \mathrm{mg} / \mathrm{dm}^{3}$
}

The share of wastewater from the vacuum trucks in the whole volume wastewater flowing into the sewage treatment plant in 2011-2013 ranged from 0.8 to $4.0 \%$, and industrial waste water from 4.4 to $11.0 \%$ [5]. The average amount of wastewater fed to the treatment plant during the analysed period was $3720 \mathrm{~m}^{3} / \mathrm{d}$, which represents $62.5 \%$ of the designed capacity of the Wastewater treatment plant.

\section{RESULTS AND DISCUSSION}

\subsection{Evaluation of wastewater treatment plants}

The amount of raw sewage flowing into the treatment plant in 2011-2013 (Fig. 1) Were variations over time. The sharp increase was recorded during periods of intense rainfall (July) and snowmelt (March). The biggest irregularity of the amount of wastewater flowing into the treatment plant was observed in 2013.

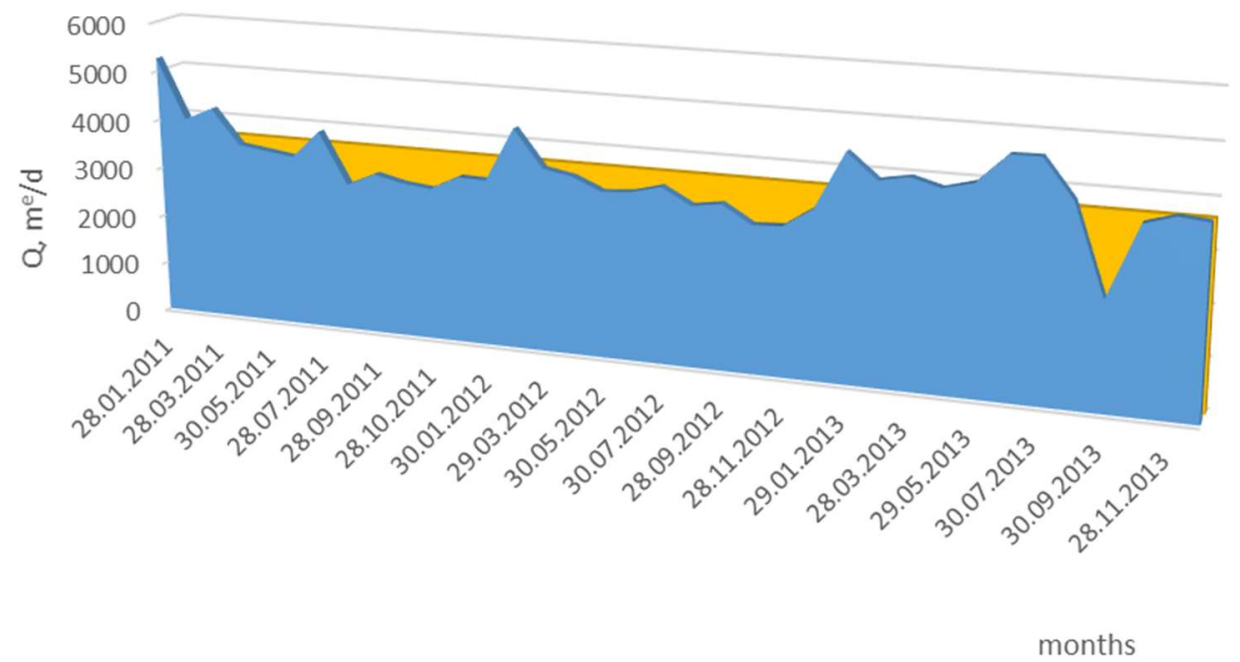

Fig. 1. Changes in the amount of wastewater flowing into the treatment plant in the period 2011-2013 
Water infiltration into drains caused a dilution of wastewater and reduction of concentrations of pollutants flowing into the treatment plant. Changes in concentration of organic compounds $\left(\mathrm{BOD}_{5}, \mathrm{COD}\right)$, and suspension and biogens depending on the amount of wastewater are shown in turn in fig. 2-4.

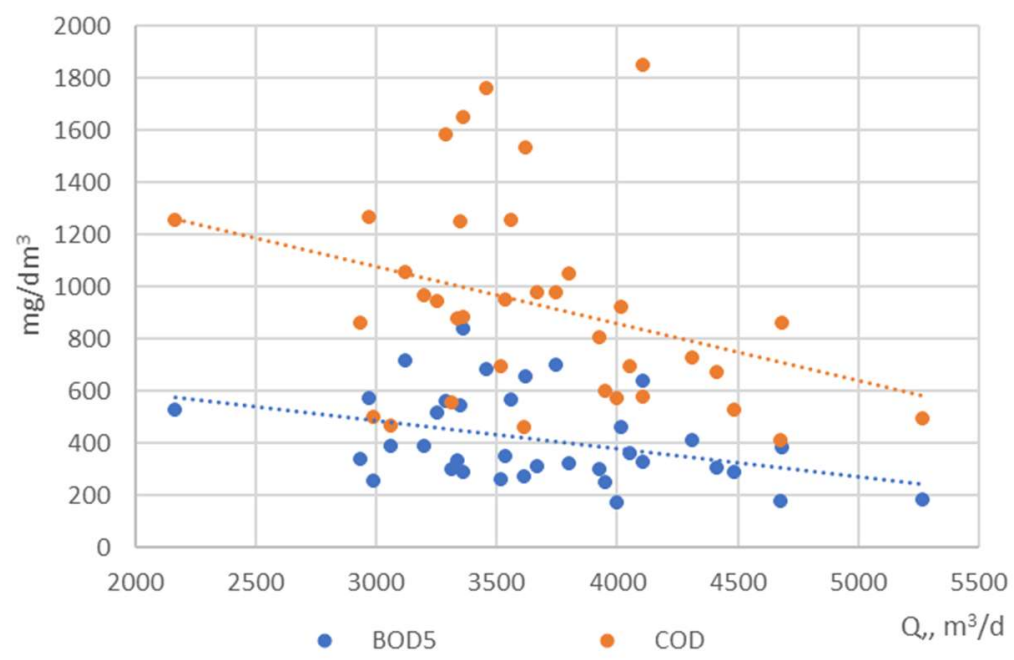

Fig. 2. The relationship between the concentration of organic compounds, and the amount of inflowing sewage in the years 2011-2013

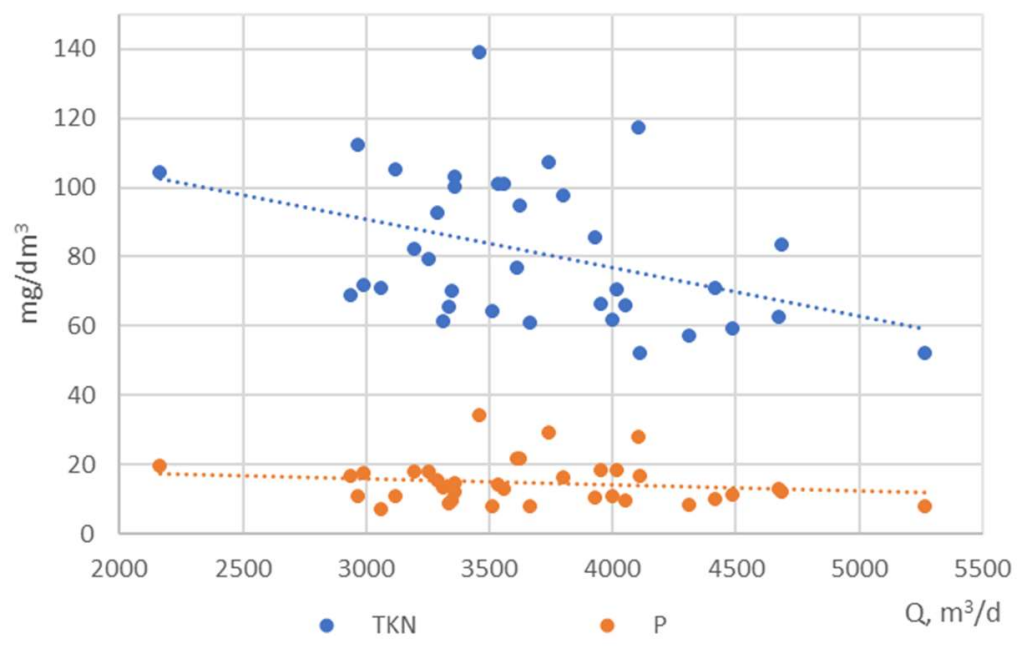

Fig. 3. The relationship between the concentration of nitrogen and phosphorus, and the amount of inflowing sewage in the years 2011-2013 


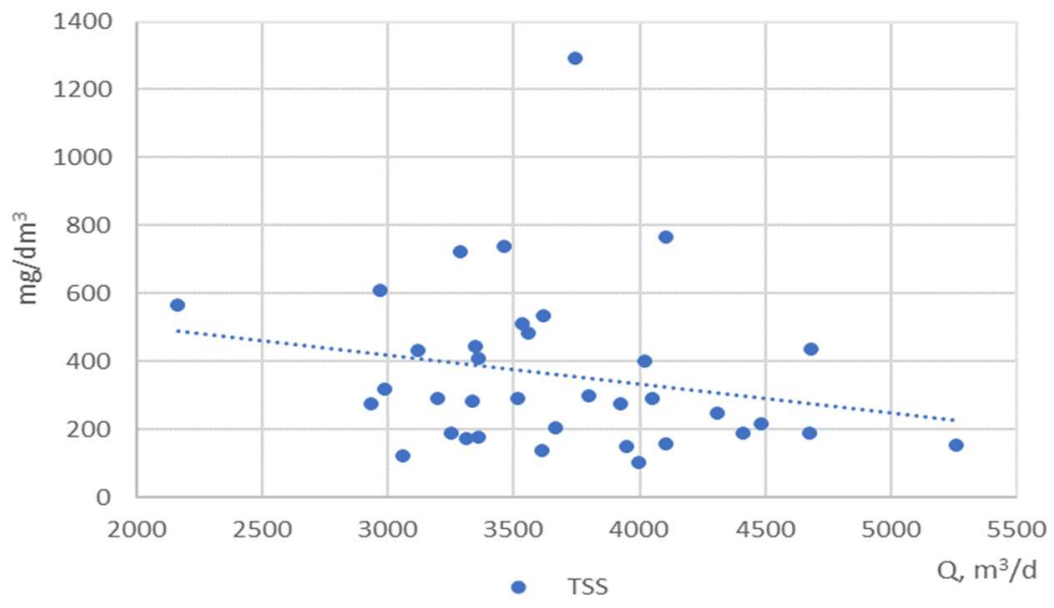

Fig. 4. The relationship between the concentration of the suspension and the amount of inflowing sewage in the years 2011-2013

The processes of biological wastewater treatment do not provide stable concentrations of total nitrogen in treating wastewater. Concentrations of nitrogen compounds oscillated in the range of 5.7 to $47.3 \mathrm{mg} / \mathrm{dm}^{3}$. Exceeding the limit value of $15 \mathrm{mg} / \mathrm{dm}^{3}$ occurred primarily during periods of low temperatures (Table 2).

\subsection{Assessment of nitrification and denitrification process}

In the wastewater treatment plant processes of nitrification and denitrification take place simultaneously in the ditch biological. The parameters for assessing the wastewater biological processes are summarized in Table 2 .

The concentrations of total nitrogen in the raw wastewater ranged from 51.9 to $139.0 \mathrm{mg} / \mathrm{dm}^{3}$, the removal efficiency of 33.4 to $94.7 \%$. The values of the ratio $\mathrm{COD} / \mathrm{BOD}_{5}$ in raw sewage oscillated between 1.2 and 3.4.

In the $50 \%$ of cases the ratio of $\mathrm{COD} / \mathrm{BOD}_{5}$ was below 2.2 what qualifies sewage to easily degradable.

The values of the ratio of $\mathrm{BOD}_{5} / \mathrm{TKN}$ changed in the range of 2.7 to 8.1 . High values of this ratio $(>3)$ lead to a reduction in the efficiency of the nitrification process associated with the decrease of the nitrifying bacteria in the microbial population (Table 1). The values of the ratio beyond the scope of 3.5-5 [2] indicate that the wastewater conditions are not fulfilled for classical denitrification. The $\mathrm{pH}$ values of the raw wastewater varied in the range 7.2-9 for nitrification, and exceed the scope 6.5-7.5 for denitrification. Temperature of raw sewage depending on the time of year ranged from 8.4 to $22.2{ }^{\circ} \mathrm{C}$. 
Table 2. Parameters of sewage and removal efficiency of nitrogen compounds

\begin{tabular}{|c|c|c|c|c|c|c|c|}
\hline Date & $\begin{array}{c}\text { TKN in raw } \\
\text { wastewater, } \\
\mathrm{mg} / \mathrm{dm}^{3}\end{array}$ & $\begin{array}{c}\text { TKN in treated } \\
\text { wastewater, } \\
\mathrm{mg} / \mathrm{dm}^{3}\end{array}$ & $\begin{array}{c}\text { Efficiency of } \\
\text { nitrogen removal, } \\
\% \\
\end{array}$ & $\mathrm{COD} / \mathrm{BOD}_{5}$ & $\mathrm{BOD}_{5} / \mathrm{TKN}$ & $\mathrm{pH}$ & 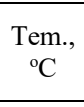 \\
\hline 28.01 .11 & 51.9 & 16.3 & 68.6 & 2.7 & 3.4 & 7.8 & 10.2 \\
\hline 28.02 .11 & 65.8 & 24.3 & 63.1 & 1.9 & 5.4 & 8.1 & 8.4 \\
\hline 28.03 .11 & 57.0 & 18.6 & 67.4 & 1.8 & 7.2 & 7.8 & 11.4 \\
\hline 28.04 .11 & 76.8 & 14.8 & 80.7 & 1.7 & 3.5 & 7.8 & 16.8 \\
\hline 30.05 .11 & 101.0 & 12.9 & 87.2 & 2.7 & 3.5 & 7.8 & 19.0 \\
\hline 28.06 .11 & 139.0 & 12.8 & 90.8 & 2.6 & 4.9 & 7.7 & 21.0 \\
\hline 28.07 .11 & 70.3 & 10.9 & 84.5 & 2.0 & 6.5 & 7.6 & 20.7 \\
\hline 28.08 .11 & 71.5 & 11.3 & 84.2 & 2.0 & 3.5 & 7.6 & 22.2 \\
\hline 28.09 .11 & 79.2 & 12.0 & 84.8 & 1.8 & 6.5 & 7.6 & 20.3 \\
\hline 28.10 .11 & 105.0 & 15.5 & 85.2 & 1.5 & 6.8 & 7.4 & 16.2 \\
\hline 28.11 .11 & 70.7 & 13.7 & 80.6 & 1.2 & 5.5 & 8.4 & 12.8 \\
\hline 22.12 .11 & 70.1 & 8.6 & 87.7 & 2.3 & 7.7 & 7.1 & 11.4 \\
\hline 30.01 .12 & 65.3 & 36.1 & 44.7 & 2.6 & 5.1 & 7.7 & 9.5 \\
\hline 28.02 .12 & 71.0 & 47.3 & 33.4 & 2.2 & 4.3 & 7.7 & 9.7 \\
\hline 29.03 .12 & 60.8 & 15.6 & 74.3 & 3.1 & 5.1 & 7.4 & 13.9 \\
\hline 26.04 .12 & 101.0 & 13.9 & 86.2 & 2.2 & 5.6 & 7.5 & 15.3 \\
\hline 30.05 .12 & 61.4 & 9.1 & 85.2 & 1.9 & 4.8 & 7.8 & 19.8 \\
\hline 28.06 .12 & 100.0 & 12.1 & 87.9 & 3.0 & 2.9 & 7.4 & 19.5 \\
\hline 30.07 .12 & 64.2 & 8.0 & 87.5 & 2.6 & 4.1 & 7.6 & 23.0 \\
\hline 29.08 .12 & 82.1 & 17.7 & 78.4 & 2.5 & 4.7 & 7.7 & 21.9 \\
\hline 28.09 .12 & 92.7 & 10.7 & 88.5 & 2.8 & 6.0 & 7.5 & 19.6 \\
\hline 29.10 .12 & 68.8 & 7.3 & 89.4 & 2.5 & 4.9 & 7.6 & 15.5 \\
\hline 28.11 .12 & 112.0 & 13.9 & 87.6 & 2.2 & 5.1 & 7.5 & 14.0 \\
\hline 20.12 .12 & 103.0 & 16.5 & 84.0 & 2.0 & 8.1 & 7.1 & 11.9 \\
\hline 29.01 .13 & 59.0 & 25.8 & 56.3 & 1.8 & 4.8 & 7.5 & 9.7 \\
\hline 28.02 .13 & 61.6 & 23.6 & 61.7 & 3.4 & 2.7 & 7.7 & 9.8 \\
\hline 28.03 .13 & 52.2 & 23.2 & 55.6 & 1.8 & 6.2 & 7.6 & 10.5 \\
\hline 29.04 .13 & 66.2 & 8.7 & 86.8 & 2.4 & 3.7 & 7.5 & 16.1 \\
\hline 29.05 .13 & 117.0 & 7.8 & 93.3 & 2.9 & 5.4 & 7.3 & 15.9 \\
\hline 28.06 .13 & 62.6 & 12.8 & 79.6 & 2.3 & 2.8 & 7.6 & 17.9 \\
\hline 30.07 .13 & 83.3 & 7.1 & 91.5 & 2.3 & 4.6 & 7.6 & 20.8 \\
\hline 29.0813 & 85.5 & 11.8 & 86.2 & 2.7 & 3.5 & 7.1 & 20.2 \\
\hline 30.09 .13 & 104.0 & 17.0 & 83.7 & 2.4 & 5.0 & 7.6 & 18.5 \\
\hline 30.10 .13 & 94.4 & 13.0 & 86.2 & 2.3 & 6.9 & 7.8 & 18.0 \\
\hline 28.11 .13 & 97.3 & 14.2 & 85.4 & 3.3 & 3.3 & 9.0 & 14.8 \\
\hline 20.12 .13 & 107.0 & 5.7 & 94.7 & 1.4 & 6.5 & 6.5 & 13.1 \\
\hline
\end{tabular}

When analysing the correlation between the concentrations of total nitrogen in treating wastewater and the ratio of $\mathrm{BOD}_{5} / \mathrm{TKN}$, and the temperature it was found 
that the effectiveness of nitrogen removal was primarily determined by the temperature of wastewater (Fig. 5-8).

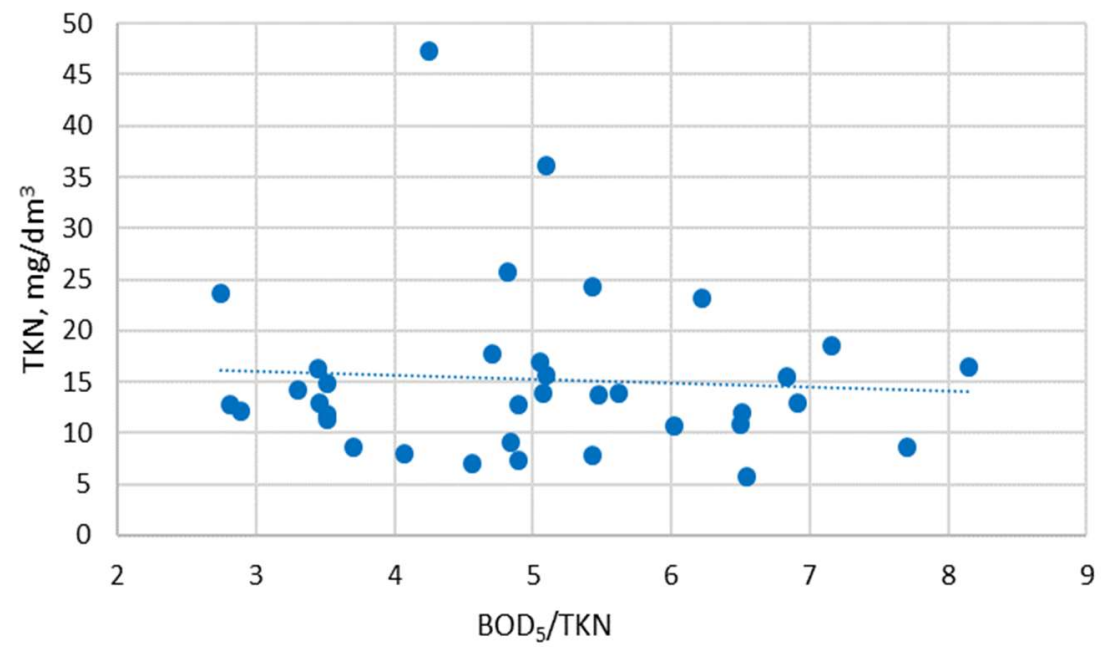

Fig. 5. The relationship between the nitrogen concentration of the treated wastewater and the ratio of $\mathrm{BOD}_{5} / \mathrm{TKN}$

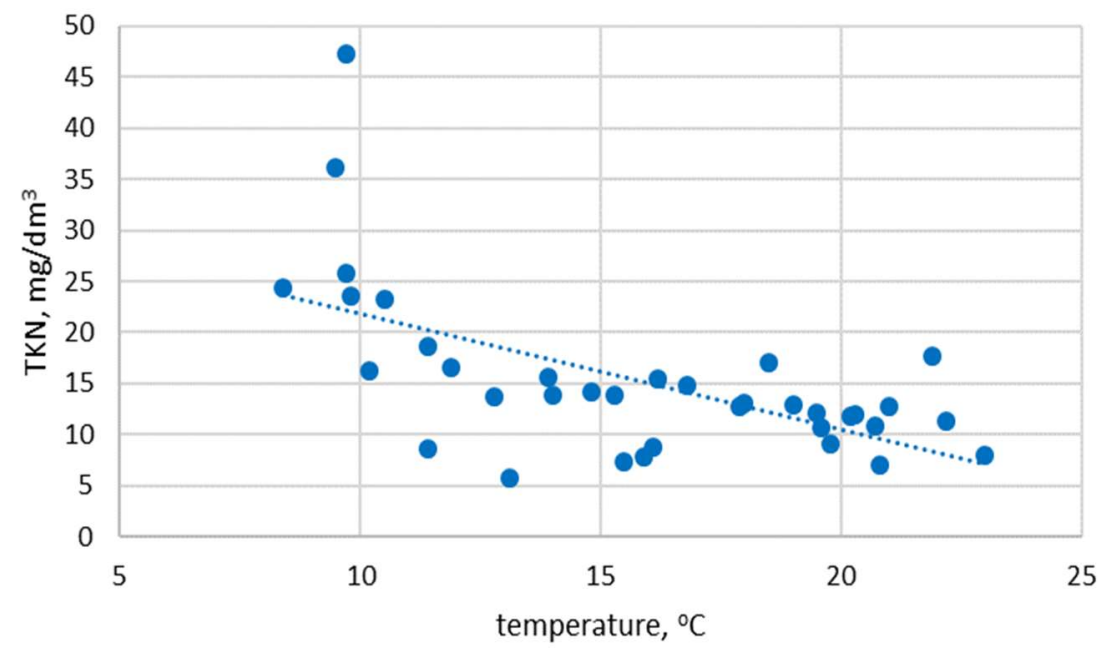

Fig. 6. The relationship between the nitrogen concentration and the temperature of the treated wastewater

The data shown in Fig. 6 confirm that with increasing temperature have reduced the concentration of nitrogen in the treated wastewater. At temperatures below 
$10^{\circ} \mathrm{C}$ is not achieved effective process of denitrification, which confirms the increase in the concentration of nitrogen in treated wastewater (Fig. 6) and a decrease the efficiency of nitrogen removal (Fig. 7).

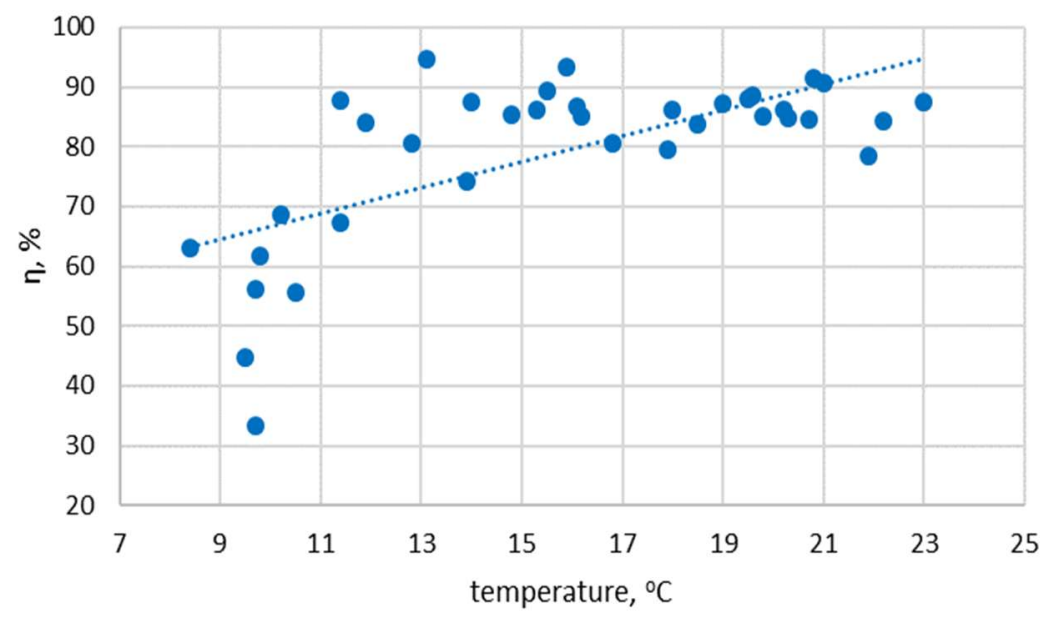

Fig. 7. The relationship between the efficiency of nitrogen removal and the temperature

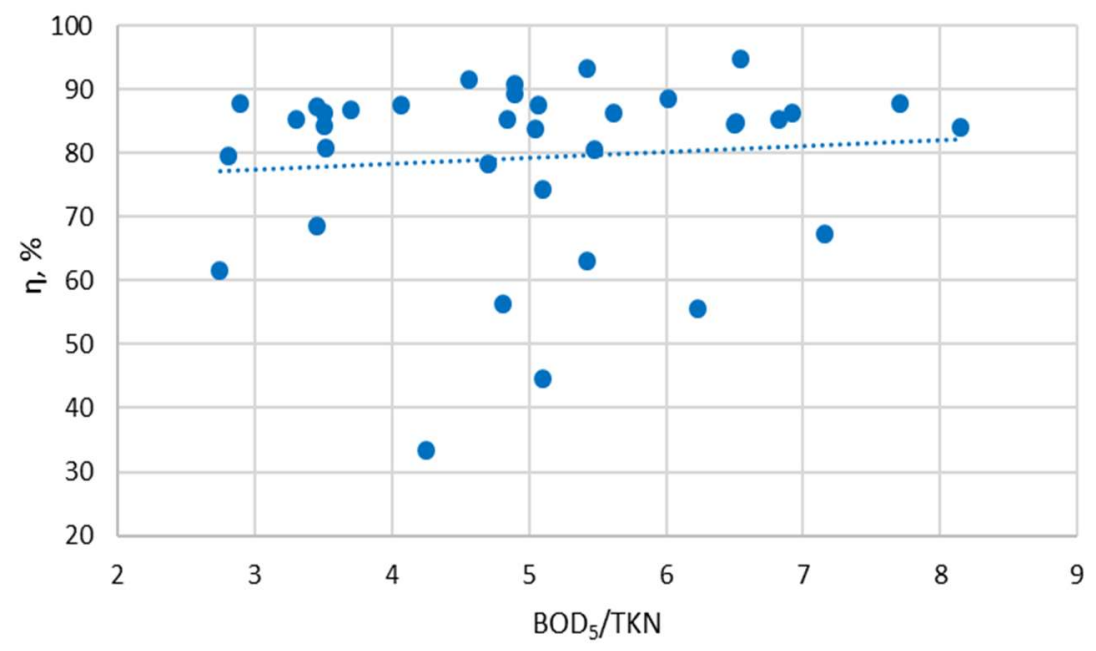

Fig. 8. The relationship between the efficiency of nitrogen removal and the quotient of $\mathrm{BOD}_{5} / \mathrm{TKN}$

Statistical evaluation of the relationship between the efficiency of removal of nitrogen and the ratio of $\mathrm{BOD}_{5} / \mathrm{TKN}$ (Fig. 8) Indicates a high fluctuation of the 
efficiency of total nitrogen removal from wastewater in the range from 30 to $>90 \%$ for various values of the ratio of $\mathrm{BOD}_{5} / \mathrm{TKN}$.

Even at the optimal ranges of $\mathrm{BOD}_{5} / \mathrm{TKN}$ at temperature under $10^{\circ} \mathrm{C}$ nitrogen concentration in the treated wastewater was even about 3 times higher than the limit value (Table 2) and nitrogen removal efficiency was in the range of 30 to about $60 \%$ (Fig. 8 ).

\section{CONCLUSION}

Analysis of effluent treatment work has shown that:

- Wastewater treatment plant varying load of pollution caused by the inflow of water infiltration, especially in periods of rainfall and snowmelt spring,

- A technological, mechanical-biological treatment provides high-efficient removal from wastewater organic compounds and throughout the analysed period, the value of $\mathrm{BOD}_{5}$ and $\mathrm{COD}$ in treating wastewater does not exceed the limit values for this type of treatment,

- High efficiency removal of phosphorus from wastewater is achieved through the use of the chemical precipitation process,

- Efficiency of removal of nitrogen compounds was variable in time and depends on the temperature of sewage and the ratio of $\mathrm{BOD}_{5} / \mathrm{TKN}$.

Even at the optimal ranges of $\mathrm{BOD}_{5} / \mathrm{TKN}$ at temperature under the $10^{\circ} \mathrm{C}$ nitrogen concentration in the treated wastewater was even about 3 times higher than the limit value and nitrogen removal efficiency were in the range of 30 to about $60 \%$. The variable ratio $\mathrm{BOD}_{5} / \mathrm{TKN}$ in the range of 2.7 to 8.1 affected the efficiency of both the nitrification and denitrification.

\section{REFERENCES}

1. Heidrich Z., Kalenik M., Podedworna J., Stańko G.: Sanitation village. Publishing House "Seidel-Przywecki" Sp. o.o., Warsaw 2008.

2. Henze M.: Wastewater treatment. Biological and chemical processes, Ed. Kielce University of Technology, Kielce 2000.

3. Janosz-Rajczyk, M.: Biological methods for removing nitrogen from selected rainwater, A series of monographs 102, ed. Czestochowa University of Technology, Czestochowa 2004.

4. Mielcarek A., Rodziewicz J., Kupczyk K., Rokicka M., Effect of types of external organic carbon source for the denitrification rate, Interdisciplinary issues in engineering and environmental protection, ed. T. M. Traczewski and B. Kazmierczak, University of Technology Press, Wroclaw 2014,543-551. 
5. Operating data operation of sewage treatment plants in the years $2011-2013$. The company Communal Economy (archive materials).

6. Regulation of the Minister of the Environment of November 18, 2014 on conditions to be met when introducing sewage into waters or into the ground, and on substances particularly harmful to the water environment - Journal of laws 2014 poz. 1800.

7. Sadecka Z., 2010. Fundamentals of biological wastewater treatment, ed. Seidel-Przywecki, Warsaw.

8. Sadecka Z., Mazurkiewicz M.: Conditions denitrification process on the example of the treatment plant in Kostrzyn, University of Zielona Góra, Scientific Papers 142, 22 (2011) 35-43.

9. Sadecka Z., Jedrczak A., Pluciennik-Koropczuk E., Myszograj S., Suchowska-Kisielewicz M.: COD Fractions in Sewage Flowing into Polish Sewage Treatment Plants, Chemical and Biochemical Engineering Quarterly, 27, 2 (2013) 185-195.

10. Szewczyk K.W.: Biological methods for removing nitrogen from wastewater, Ed. Publishing House of Warsaw University of Technology, Warsaw 2005.

\section{OCENA EFEKTYWNOŚCI PRACY OCZYSZCZALNI ŚCIEKÓW O RLM 45000}

\section{Streszczenie}

W oczyszczalniach mechaniczno-biologicznych do usuwania związków azotu wykorzystuje się biologiczne procesy nitryfikacji i denitryfikacji. Usuwanie fosforu odbywa się przy wykorzystaniu metod biologicznych lub chemicznych. Sprawność procesów biologicznych wymaga odmiennych warunków środowiskowych tzn. tlenowych dla nitryfikacji, a beztlenowych dla denitryfikacji, czy tez warunków beztlenowo-tlenowych dla defosfatacji biologicznej. Parametrami decydującymi o sprawności procesów biologicznych usuwania azotu są: stosunek węgla organicznego $\left(\mathrm{BZT}_{5}\right)$ do ogólnego azotu Kjeldahla (TKN), temperatura i odczyn środowiska. Wpływ tych parametrów na pracę oczyszczalni o RLM 45000 oceniono na podstawie danych eksploatacyjnych z okresu 2011-2013. Efektywność usuwania związków azotu ze ścieków w analizowanej oczyszczalni zależała od temperatury ścieków oraz ilorazu $\mathrm{BZT}_{5} / \mathrm{TKN}_{\text {Zmienne wartości ilorazu BZT }} \mathrm{TKKN}_{\mathrm{T}}$ zakresie od 2,7 do 8,1, wpływały na uzyskiwaną efektywność zarówno procesu nitryfikacji, jak i denitryfikacji. Nawet przy optymalnych zakresach $\mathrm{BZT}_{5} \mathrm{TKN} \mathrm{w}$ temperaturze poniżej $10^{\circ} \mathrm{C}$ stężenia azotu w ściekach oczyszczonych były nawet o około 3-krotnie wyższe od wartości dopuszczalnej, ze sprawnością usuwania azotu w zakresie od 30 do $60 \%$.

Słowa kluczowe: usuwanie związków azotu, $\mathrm{BZT}_{5} / \mathrm{TKN}$, temperatura ścieków

Editor received the manuscript: 19.09 .2018 